\title{
Liquidity Shocks, Real Interest Rates, and Global Imbalances
}

\author{
David Andolfatto
}

The author uses a simple neoclassical model to show how liquidity shocks at home and abroad can contribute to trade imbalances and low real interest rates. The author's interpretation is consistent with Bernanke’s (2005) "global saving glut" hypothesis. (JEL E2, F3)

Federal Reserve Bank of St. Louis Review, May/June 2012, 94(3), pp. 187-95.

D ecent decades have witnessed a steady decline in the real interest rates associated with relatively low-risk securities. Indeed, the real yields on short- to mid-term dated U.S. Treasury securities are presently negative (Figure 1). Over roughly the same period of time, the world economy has exhibited growing trade imbalances-a second phenomenon that refers primarily to the large and persistent U.S. current account deficits, financed in large part by emerging economies (Figure 2). The question I ask in this article is whether these two phenomena are related and, if so, what is the underlying economic mechanism?

I am not, of course, the first one to ask this question. There is, by now, a large (and still growing) literature on the subject. As usual, there is likely no single reason behind the phenomena and, as one would expect, the literature offers several candidate explanations. It is possible, however, to identify a common theme in these explanations-namely, the existence of a financial market "friction" that gives rise to a localized borrowing constraint. 1 Typically, the friction plays a passive role in the sense that it interacts only with some other shock—such as an increase in growth or uncertainty-to explain the phenomena under investigation. Instead, in this article I take a different approach: to investigate whether the direct effect emanating from a change in the friction itself might also account for global imbalances and declining interest rates.

I model borrowing constraints below as the product of a limited commitment friction. "Limited commitment" refers to the unwillingness of debtors to honor their promises of repayment. On the flip side, it refers to the inability of creditors to recover all that is owed to them (in circumstances where debtors have the means to repay). Hence, limited commitment gives rise to the possibility of "strategic default." 2 Because creditors are generally aware of the incentive to

David Andolfatto is a vice president and economist at the Federal Reserve Bank of St. Louis. The author thanks his colleagues Fernando Martin, Yi Wen, and B. Ravikumar for helpful comments and Constanza Liborio for research assistance.

(c) 2012, The Federal Reserve Bank of St. Louis. The views expressed in this article are those of the author(s) and do not necessarily reflect the views of the Federal Reserve System, the Board of Governors, or the regional Federal Reserve Banks. Articles may be reprinted, reproduced, published, distributed, displayed, and transmitted in their entirety if copyright notice, author name(s), and full citation are included. Abstracts, synopses, and other derivative works may be made only with prior written permission of the Federal Reserve Bank of St. Louis. 


\section{Andolfatto}

\section{Figure 1}

\section{Real Interest Rates}

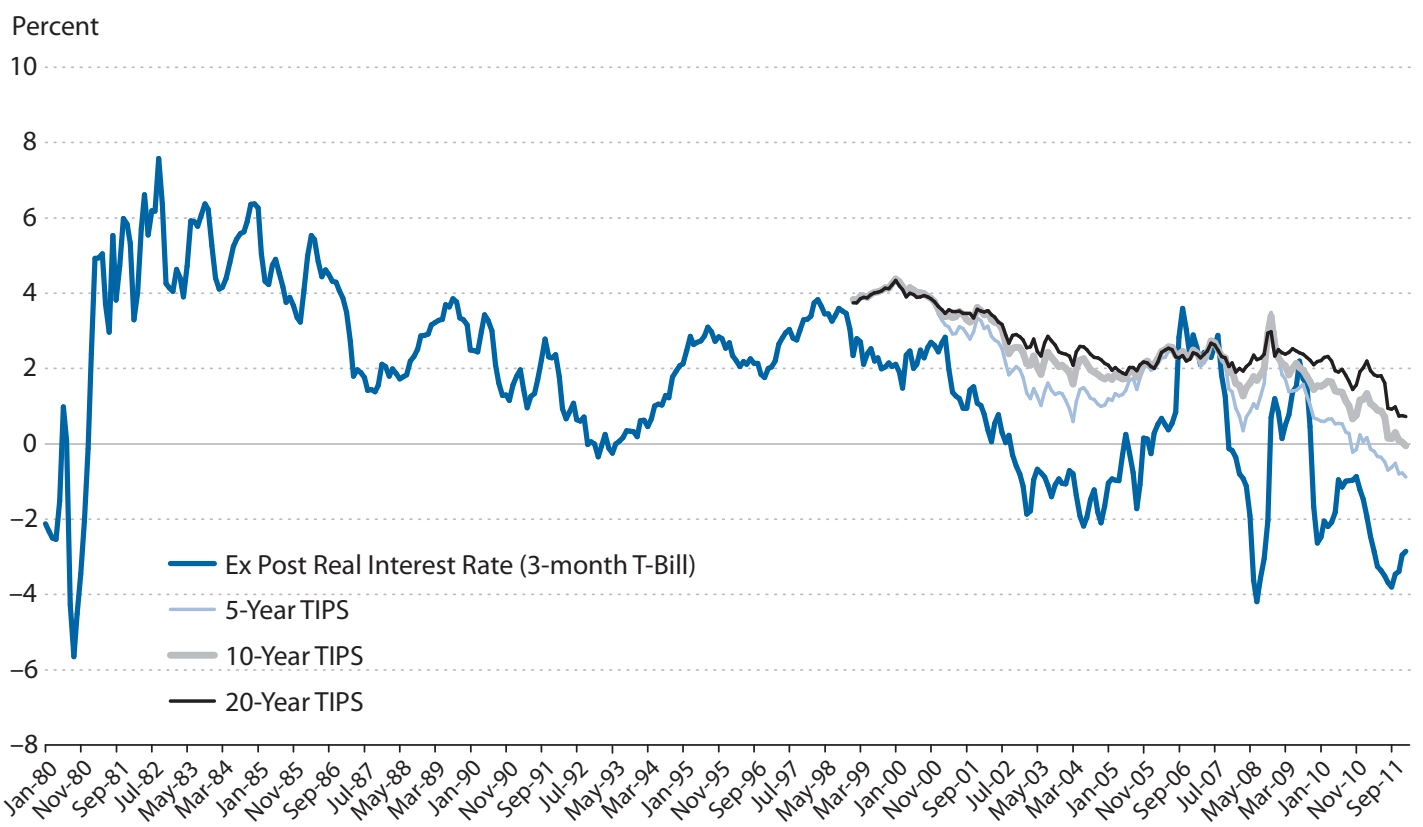

NOTE: TIPS, Treasury inflation-protected securities.

Figure 2

\section{Current Account Balances}

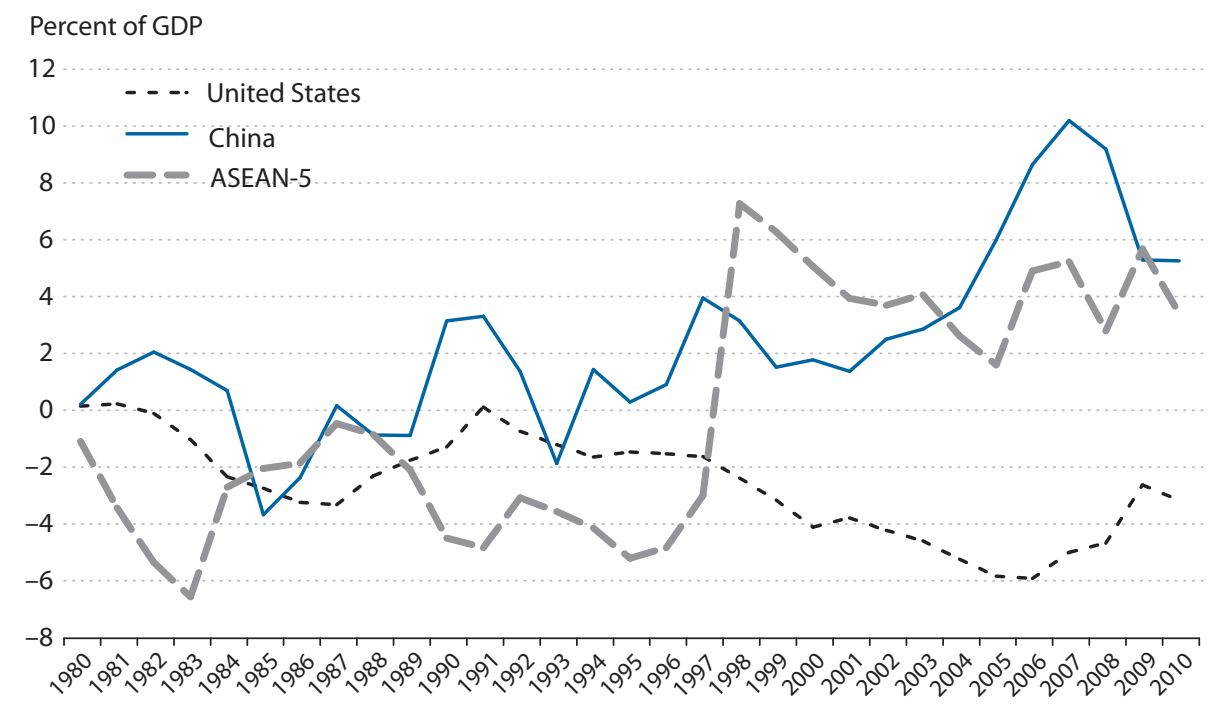

NOTE: The ASEAN-5 countries are Indonesia, Malaysia, the Philippines, Singapore, and Thailand. 


\section{Figure 3}

\section{World Gross Saving}

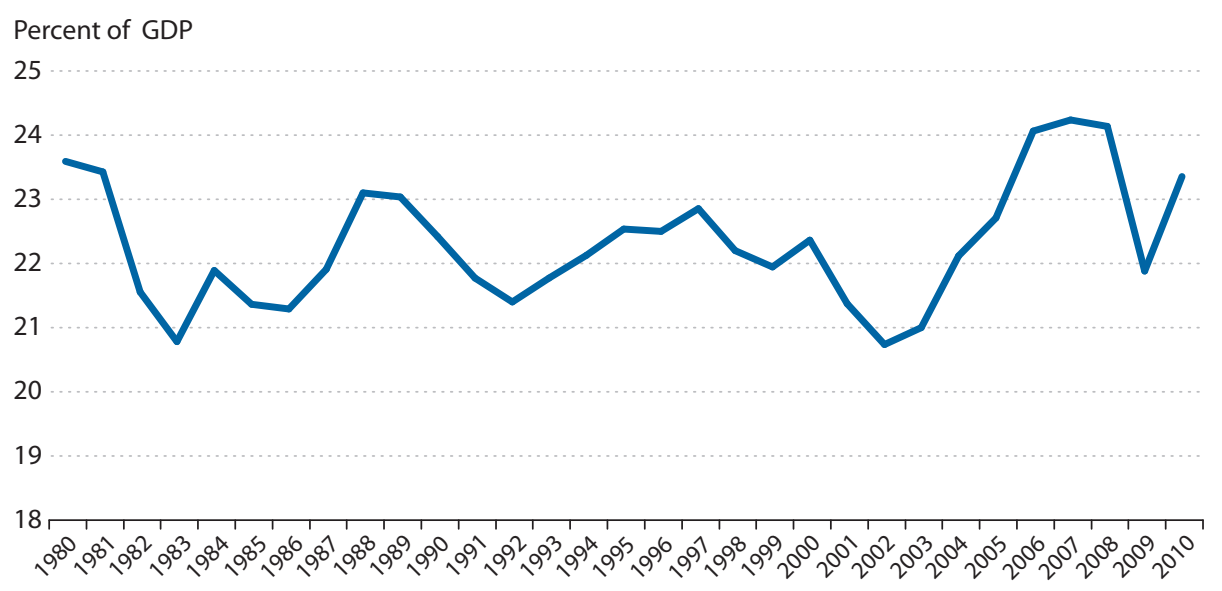

default, their natural response is to ration credit and/or demand collateral in support of a debt arrangement. $\underline{3}$

When assets can be used as collateral, they can, in effect, be used to pay for things. In this sense, collateral instruments are similar to monetary instruments. And just as with our experience with monetary instruments throughout history, different forms of collateral can very quickly become more or less "liquid" depending on how market participants view the quality of the underlying collateral assets. A sudden change in market perception-whether warranted or not-may lead to heavy discounts ("haircuts") on the face value of collateral. A drop in the perceived value of collateral, in turn, leads to increased concern over the possibility of strategic default, and with it, an associated contraction in credit supply. I label such an event a liquidity shock. And, as the title of this article suggests, I consider how a sequence of liquidity shocks could have contributed to the phenomenon of global imbalances and low interest rates.

This line of inquiry is motivated in part by a famous speech by Federal Reserve Chairman Ben Bernanke (2005) entitled "The Global Saving Glut and the U.S. Current Account Deficit." As Figure 3 clearly shows, there is, in fact, little evidence of a secular increase in the global saving rate. However, it also seems clear that what Bernanke means by a "saving glut" is a reallocation of world saving toward relative safe havens, primarily the United States. In particular, he states that "a key reason for the change in the current account position of developing countries is the series of financial crises those countries experienced in the past decade or so." He goes on to cite a loss of lender confidence (and other factors) that ultimately culminated in a series of financial crises in Mexico in 1994, in several East Asian countries in 1997-98, in Russia in 1998, in Brazil in 1999, and in Argentina in 2002. Each of these crises was characterized by (among other things) rapid capital outflows and recession. $\underline{4}$

Below I describe a way to formalize my interpretation of Bernanke's saving glut hypothesis. I begin with a simple closed economy model and show how a negative liquidity shock can reallocate a given quantity of saving from high- to low-return uses-a sort of flight to safety phenom- 
enon that leads naturally to a lower real rate of interest (and a contraction in real gross domestic product [GDP]). I then extend the model to allow for international trade and finance. A sequence of negative liquidity shocks originating outside the domestic sector now generates an inflow of capital from foreign locations, with the effect of depressing real yields in the face of mounting current account deficits.

\section{A CLOSED ECONOMY MODEL}

My framework of analysis is the overlapping-generations model. $\frac{5}{\text { Time is discrete and the }}$ time horizon is infinite; denote time by $t=1,2, \ldots, \infty$. Let $N_{t}$ denote the number of people who enter the economy at date $t \geq 1$ (the "young"). Those who enter at dates $t \geq 1$ participate ("live") for two periods and then exit the economy (they "die"). At the beginning of time, there is an incumbent population $N_{0}$ of "initial old" agents who live for one period only. There is no uncertainty and, for simplicity, I assume $N_{t}=1$ for all $t$. That is, the population is constant and at any point in time divided evenly between the young and old. All agents wish to consume in the second period of life only. -6 Moreover, I assume that preferences are linear in the level of consumption.

Agents enter the economy as one of two types: workers and entrepreneurs (assume equal numbers of each). Workers are endowed with $y$ units of output when young. ${ }^{-}$Workers possess a means to store wealth (a storage technology) that yields a gross real rate of return $0<\delta>1$. Entrepreneurs are endowed with a capital project that transforms $k_{t}$ units of investment at date $t$ into $f\left(k_{t}\right)$ units of output at date $t+1$. Capital depreciates fully after it is used in production. Assume that $f^{\prime \prime}<0<f^{\prime}, f(0)=0, f^{\prime}(0)=\infty$, and $f^{\prime}(y)>\delta$.

Workers are the natural savers here and entrepreneurs the natural borrowers. Assume a competitive market for loanable funds and let $R$ denote the gross real rate of interest. As the young wish to postpone their consumption, their saving in aggregate is equal to $y$. Entrepreneurs wish to borrow resources to fund capital investment. Investment demand $k^{d}$ satisfies $f^{\prime}\left(k^{d}\right)=R$. In equilibrium $k^{d}=y$, which implies an equilibrium interest rate ${ }^{\underline{8}}$ as follows:

$$
R^{*}=f^{\prime}(y)
$$

Workers consume $c_{w}^{*}=R^{*} y$ and entrepreneurs consume $c_{e}^{*}=f(y)-R^{*} y$.

In this model, the equilibrium interest rate is determined by whatever forces influence desired saving and investment. An exogenous increase in saving, $y$, serves to reduce the interest rate. An exogenous decline in the expected marginal product of capital schedule $f^{\prime}(k)$ similarly has the effect of depressing the interest rate, owing to a contraction in investment demand. In what follows, I abstract from these "neoclassical" considerations to focus on another type of shock that seems better suited to describing what happens during a financial crisis.

\section{LIMITED COMMITMENT AND LIQUIDITY CONSTRAINTS}

Young entrepreneurs want to borrow to finance new capital formation. The analysis above implicitly assumes that entrepreneurs can be relied on to repay their debts. Assume instead that entrepreneurs lack the commitment necessary to make good on their unsecured promises. 
Following Kiyotaki and Moore (2002), assume that some fraction $0 \leq \theta \leq 1$ of the future return to investment $f(k)$ can be pledged as collateral in support of debt. Consequently, entrepreneurs are subject to a debt constraint that takes the form

$$
R k \leq \theta f(k) .
$$

The parameter $\theta$ indexes the extent to which capital projects are "liquid" - that is, how easily they can be used to pay for things (such as the resources acquired from young workers in this case). For this reason, it seems appropriate to label unexpected changes in $\theta$ liquidity shocks. But before studying the effects of an unanticipated change in liquidity, let us first study the implications of the liquidity constraint (2) for the interest rate and resource allocation.

The liquidity constraint (2) either binds or it does not. If it does not bind, then the equilibrium is as described above. But clearly, there exists a small enough $\theta$ that will render the liquidity constraint tight. For example, if capital projects are perfectly illiquid $(\theta=0)$, then entrepreneurs secure zero financing and workers invest their income $y$ in savings for future return $\delta y$.

The example just considered suggests that the interest rate in the liquidity-constrained economy is equal to $\delta<f^{\prime}(k)$. Indeed, this turns out to be the case. ${ }^{9}$ Consequently, if condition (2) binds, then capital spending on the part of entrepreneurs $\hat{k}<y$ satisfies

$$
\delta \hat{k}=\theta f(\hat{k}) .
$$

Suppose $f^{\prime}(k) k=\alpha f(k)$ for some $0<\alpha<1$. Then condition (3) can be expressed as $\delta=(\theta / \alpha) f^{\prime}(\hat{k})$. Define $0<\theta^{*}<1$ that satisfies

$$
\left(\theta^{*} / \alpha\right) f^{\prime}(y)=\delta
$$

Clearly, $\theta^{*}<\alpha$ since $f^{\prime}(y)>\delta$. We conclude from equation (4) that the debt constraint will bind tightly for any value of $0 \leq \theta<\theta^{*}$. Moreover, note that when the debt constraint does bind, the rate of return on capital exceeds the interest rate-that is, $f^{\prime}(\hat{k})>\delta$. This high rate of return cannot be exploited here because entrepreneurs will default on any debt in excess of $\hat{k}$. Anticipating this, creditors (here, workers) impose a credit limit on entrepreneurs. The credit limit is chosen such that entrepreneurs have no incentive to default in equilibrium - at least, barring any unforeseen changes in the environment, which I address momentarily.

I conclude this section by noting the impact of the liquidity constraint on resource allocation and welfare. First, in this simple model, there is no impact on aggregate investment. Rather, the effect of the constraint here is a misallocation of resources across investment opportunities. Ideally, all of $y$ should be allocated to entrepreneurs. When the liquidity constraint binds, however, only $\hat{k}<y$ units are allocated to entrepreneurs who generate $f(\hat{k})$ units of output, with the remaining $y-\hat{k}$ units invested in the low-return storage technology, generating future output $\delta(y-\hat{k})$. Note that $f(k)>f(\hat{k})+\delta(y-\hat{k})$; thus, the effect of the constraint is to lower real GDP. The economic welfare of both workers and entrepreneurs is lower when the liquidity constraint binds. 


\section{A FINANCIAL CRISIS}

Consider the following thought experiment. Imagine an economy initially functioning at a high level where liquidity is not a concern. Entrepreneurs are fully financed, and savers enjoy a high rate of interest on their savings - that is, condition (1) holds.

Suppose now that in some arbitrary period, the parameter $\theta$ suddenly jumps down to a level less than $\theta^{*}$; that is, there is a negative liquidity shock. Assume that the shock occurs just after entrepreneurs have secured full funding. For simplicity, assume that the shock is perceived to be permanent.

One way to interpret the shock is to imagine that debtors are suddenly presented with an opportunity for strategic default. That is, while the current-generation entrepreneurs have borrowed $y$ and are expected to repay $R^{*} y$, they now repay only what they absolutely have to: $\theta f(y)<R^{*} y$. Hence, if they can do so with impunity, debtors abscond with the amount $R^{*} y-\theta f(y)>0$ at the expense of savers.

The decline in $\theta$ corresponds to an evaporation of investor confidence here, confidence that one will be repaid. Savers do not believe the promises made by creditors; this suspension of belief generates a "credit crisis." 10 As a result, savers ration the credit they supply to entrepreneurs, diverting resources to more secure, though less productive, investment opportunities. The real interest rate declines, and the economy enters a recession.

The purpose of this section was to demonstrate how a domestic liquidity crisis leads to a low-possibly negative-real rate of interest. Essentially, capital is diverted from high-return (but untrustworthy) to low-return (and safer) uses. Next I want to show that the same effect is possible for the domestic economy even if the crisis occurs in foreign sectors with trading links to the domestic economy.

\section{A TWO-COUNTRY MODEL}

Imagine now that there are two countries, each like the one described above. Let me call country 1 the United States and country 2 the rest of the world (ROW). If the countries are identical in every respect, then there is no international trade and the competitive equilibrium is as described above. I use the unconstrained equilibrium as my starting point.

My intended experiment here is a sequence of negative liquidity shocks in the ROW-that is, declines in the value of $\theta$ that leave entrepreneurs in the ROW liquidity-constrained. 11 As liquidity shocks generate phenomena in the model that are associated with financial crises, this thought experiment seems consistent with the view expressed by Bernanke (2005).

Consider then an unanticipated and permanent decline in foreign sector $\theta$ that is sufficiently large to constrain investment in the ROW (I assume that investment remains unconstrained in the United States). For simplicity, assume that $\delta=0$. In this event, capital investment in the ROW is determined by $R \hat{k}_{2}=\theta f\left(\hat{k}_{2}\right), \hat{k}_{2}<y$. In the United States, capital investment remains unconstrained, so $f^{\prime}\left(\hat{k}_{1}\right)=R$. Equating the world supply of saving and demand for investment, $2 y=$ $\hat{k}_{1}+\hat{k}_{2}$, it follows that $\hat{k}_{1}>\mathrm{y}>\hat{k}_{2}$ and $\hat{R}=f^{\prime}\left(\hat{k}_{1}\right)<R^{*}$.

In these open economies, capital is reallocated from the ROW to the United States, driving the marginal product of capital up in the former region and down in the latter. While the rate of 
return is high in the ROW, creditors are unable to exploit this high return for the reason discussed earlier: Debtors (in this case, foreign debtors) cannot commit to repay all their debts. Consequently, foreign savers, seeking a relative safe haven, move their savings to the United States, thereby lowering the world real rate of interest. $\underline{12}$

The asymmetric liquidity shock generates international trade flows. Suppose, for the sake of illustration, that the shock is permanent. Then in the period of the shock, the United States imports $\left(\hat{k}_{1}-y\right)>0$ units of capital; that is, there is a net inflow of capital from abroad-a U.S. trade balance deficit. In all subsequent periods, the United States simultaneously remits $\hat{R}\left(\hat{k}_{1}-y\right)$ to foreign bondholders and imports $\left(\hat{k}_{1}-y\right)>0$ of new capital. If the real rate of interest is positive (presently not the case on U.S. Treasury securities with maturities of 10 years and less), then foreign income for the United States is negative; $N F I_{1}=(\hat{R}-1)\left(y-\hat{k}_{1}\right)<0$.

The liquidity shock also induces default in the period of the shock, with corresponding wealth redistribution. On impact, old entrepreneurs in the ROW partially default on their debt obligations. These agents owe $R^{*} y \geq \theta f(y)$, so they default on the difference. Note that as individual wealth portfolios are indeterminate here, bondholders around the world could be affected. The bondholders in this case consist of the old generation of domestic and foreign workers/savers.

Depending on the duration of the liquidity shock, there are also longer-term redistributional consequences. In particular, domestic savers are harmed by lower interest rates, while domestic entrepreneurs benefit. Foreign savers benefit by the opportunity to invest domestically, while foreign entrepreneurs are harmed by a lack of funds.

\section{CONCLUSION}

Liquidity shocks-events associated with a crisis in investor confidence-are episodes that recur with discouraging regularity. While it would be of considerable interest to do so, I have not examined the deeper source of such disturbances. Instead, I simply asked the question: If we were to take liquidity shocks as given, what would they imply about global imbalances and real interest rates? I have demonstrated, within the context of a simple neoclassical model, how a sequence of liquidity shocks can generate the phenomena under investigation.

Of course, whether liquidity shocks can account for quantitative magnitudes is a separate issue. In reality, several forces likely contribute to the phenomena in question. I have cited some literature highlighting the different aspects in the process of world economic development. And while I have deliberately ignored how international policies may have influenced events, there is some evidence to suggest they have played a significant role as well (see, for example, Obstfeld and Rogoff, 2009). On the other hand, to the extent that financial markets are afflicted with limited commitment frictions, there is potential for a more positive role for policy (see, for example, Woodford, 1990). 


\section{Andolfatto}

\section{NOTES}

1 See, for example, Caballero, Farhi, and Gourinchas (2008); Mendoza, Quadrini, and Rios-Rull (2009); Song, Storesletten, and Zilibotti (2011); and the references cited therein.

$\underline{2}$ A nonstrategic default occurs when the debtor is willing but unable to repay. A strategic default occurs when the debtor is able but unwilling to repay.

3 Caballero, Farhi, and Gourinchas (2008) describe this circumstance as leading to an "asset shortage" in the sense that credit market imperfections prevent some debtors from creating what would otherwise serve as high-quality assets in the wealth portfolios of savers.

4 Bernanke goes on to speculate that in response to these crises, even emerging economies that escaped a major crisis (notably China) adopted strategies that involved shifting from being net importers of capital to being net exporters.

It is of some interest to point out that relatively mature economies such as Germany and Japan are net exporters of capital, consistent with conventional theory. It is notable too that both these economies, unlike the United States, experienced no real estate boom.

$\underline{5}$ One difficulty with the overlapping-generations framework is the tendency for readers to interpret the model too literally. I recommend that readers instead focus on the key economic forces highlighted by the model. These forces are present in infinitely lived agent economies with liquidity constraints; see, for example, Woodford (1986).

In what follows, I want to stay as simple as possible, but not so simple as to render my conclusions an artifact of the particular abstractions used for exposition. I believe the economic forces highlighted below are robust across modeling environments, although their quantitative importance may be diminished by other factors from which I abstract here.

$\underline{6}$ This assumption is made so the saving decision for young agents is exogenous; this allows me to focus on portfolio choices in the analysis to follow.

$\underline{I}$ It would be easy to endogenize output by allowing output to be an increasing function of effort, with effort subject to an increasing and convex utility cost.

8 Since $f^{\prime}(y)>\delta$, workers will prefer to lend their resources to entrepreneurs rather than invest them in their own relatively poor-return storage technology.

9 Entrepreneurs will not be able to secure additional financing by bidding up the interest rate. Consequently, the best they can do is borrow at rate $\delta$, the opportunity cost of funds to savers.

10 The word credit is itself derived from the Latin credere, which means to believe.

11 There is the question of whether one country's $\theta$ applies only to domestic entrepreneurs or to foreign entrepreneurs as well. If only the former, then the domestic liquidity constraint might be mitigated by foreign direct investment. Here, I assume that the domestic liquidity constraint applies to all agents, irrespective of their nationality. Wang, Wen, and Xu (2012) present a model wherein foreign direct investment flowing in one direction coexists with financial capital flowing in the opposite direction.

12 Thus, the model here provides one explanation for the question posed by Lucas (1990) of why capital does not flow from rich to poor countries.

\section{REFERENCES}

Bernanke, Ben. "The Global Saving Glut and the U.S. Current Account Deficit." Sandbridge Lecture, Virginia Association of Economists, Richmond, Virginia, March 10, 2005; www.federalreserve.gov/boarddocs/speeches/2005/200503102/.

Caballero, Ricardo; Farhi, Emmanuel and Gourinchas, Pierre-Olivier. "An Equilibrium Model of Global Imbalances and Low Interest Rates." American Economic Review, March 2008, 98(1), pp. 358-93.

Kiyotaki, Nobuhiro and Moore, John. "Evil Is the Root of All Money." American Economic Review, May 2002, 92(2), pp. 62-66.

Lucas, Robert E. "Why Doesn't Capital Flow from Rich to Poor Countries?" American Economic Review, May 1990, 80(2), pp. 92-96.

Mendoza, Enrique G.; Quadrini, Vincenzo and Ríos-Rull, José-Víctor. “Financial Integration, Financial Development, and Global Imbalances." Journal of Political Economy, June 2009, 117(3), pp. 371-416.

Obstfeld, Maurice and Rogoff, Kenneth (2009). "Global Imbalances and the Financial Crisis: Products of Common Causes." Unpublished manuscript, November 2009, University of California, Berkeley;

http://elsa.berkeley.edu/ obstfeld/santabarbara.pdf. 
Andolfatto

Song, Zheng; Storesletten, Kjetil and Zilibotti, Fabrizio. "Growing Like China." American Economic Review, February 2011, 101(1), pp. 196-233.

Wang, Pingfei; Wen, Yi and Xu, Zhiwei. “Two-Way Capital Flows and Global Imbalances: A Neoclassical Approach." Unpublished manuscript, Federal Reserve Bank of St. Louis, 2012.

Woodford, Michael. "Stationary Sunspot Equilibria in a Finance Constrained Economy." Journal of Economic Theory, October 1986, 40(1), pp.128-37.

Woodford, Michael. "Public Debt as Private Liquidity." American Economic Review, May 1990, 80(2), pp. 382-88. 
Close

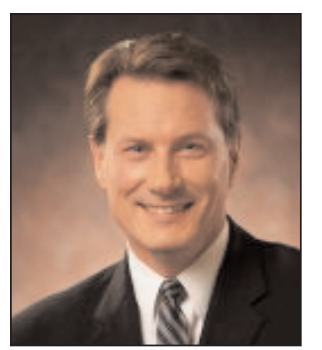

\section{David Andolfatto}

Vice president and economist, Federal Reserve Bank of St. Louis

http://research.stlouisfed.org/econ/andolfatto/

\section{Research Focus}

David Andolfatto's recent research has focused on the labor market and reconciling theories of money and banking. Past research has analyzed the business cycle, contract design, bank runs, unemployment insurance, monetary policy regimes, endogenous debt constraint, and technology diffusion. 